\title{
STRATEGI GURU DALAM MENINGKATKAN \\ MOTIVASI BELAJAR SISWA PADA MATA PELAJARAN \\ PENDIDIKAN AGAMA ISLAM KELAS VIII \\ DI SMP NAHDHOTUL ULAMA' SUNAN GIRI KEPANJEN MALANG
}

\author{
Alif Achadah \\ Universitas Islam Raden Rahmat Malang \\ Email: achadahalif@gmail.com
}

\begin{abstract}
Motivation strategy in learning is a planning towards motivation which contains a series of activities that are specifically designed and designed, to achieve various specific educational goals. Therefore, to achieve the desired educational program objectives in accordance with educational values. So that the teacher is expected to have several motivational learning strategies that can inspire students to learn comfortably, pleasantly and not monotonously. To achieve the goal of increasing student motivation, a better effort is needed from the teacher in choosing and applying motivational strategies, methods and learning media that are in accordance with these competencies. The purpose of this study is: a). Describing the teacher's strategies applied in increasing student learning motivation in class VIII Islamic Education subjects at NU Sunan Giri Kepanjen Middle School. b). Describe changes in the increase in learning motivation of VIII graders in NU Middle School Sunan Giri Kepanjen.
\end{abstract}

\section{Keywords: Strategy, Learning Motivation, PAI Lessons.}

\begin{abstract}
Abstrak
Strategi motivasi dalam pembelajaran merupakan sebuah perencanaan tehadap motivasi yang berisi serangkaian kegiatan yang di rancang dan didesain secara khusus, untuk mencapai berbagai tujuan pendidikan tertentu. Oleh karena itu, untuk mencapai tujuan program pendidikan yang diinginkan sesuai dengan nilainilai pendidikan. Sehingga guru diharapkan memiliki beberapa strategi motivasi pembelajaran yang bisa menggugah siswa untuk belajar dengan nyaman, menyenangkan dan tidak monoton. Untuk mencapai tujuan agar bisa meningkatkan motivasi siswa, maka diperlukan upaya yang lebih baik dari guru dalam memilih dan menerapkan strategi motivasi, metode beserta cara belajar yang sesuai dengan kompetensi tersebut. Tujuan penelitian ini adalah: a). Mendeskripsikan strategi Guru yang diterapkan dalam peningkatan motivasi dalam belajar siswa pada mata pelajaran PAI kelas VIII di SMP NU Sunan Giri Kepanjen. b). Mendeskripsikan perubahan peningkatan motivasi belajar siswa kelas VIII di SMP NU Sunan Giri Kepanjen.
\end{abstract}

Kata Kunci : Strategi, Motivasi Belajar, Pelajaran PAI. 


\section{A. Pendahuluan}

Pendidikan yang perlu ditingkatkan untuk membentuk generasi yang lebih baik, anak didik yang menjadi penerus bangsa. Dalam hal ini Pendidikan Agama Islam menjadi landasan penting, agar anak didik menjadi anak yang beriman dan menjadi anak didik yang mampu bertanggung jawab, jujur, berahklaq, dan berpengetahuan yang luas. Karena pendidikan adalah salah satu bentuk tabungan yang bersifat masa depan yang pendidikan tersebut dapat dijadikan sebagai sarana seseorang dalam mengaktualisasikan hidup dimasyarakat serta tidak menyusahkan orang lain. Pendidikan juga merupakan suatu lembaga yang dengan sengaja diselenggarakan untuk mewariskan dan mengembangkan pengetahuan, keahlian dan keterampilan oleh generasi yang lebih tua kepada generasi berikutnya. Dan jika pendidikan seseorang sudah maju, tentu maju pula kehidupannya demikian pula sebaliknya.

Untuk menentukan strategi apakah yang akan digunakan dalam proses pembelajaran, maka seorang guru harus menguasai beberapa metode atau strategi penyampaian materi yang tepat dalam memotivasi siswa sesuai materi keagamaan yang dalam hal ini adalah materi akhlak dalam keislaman dan kemampuan anak didik yang menerimanya. Oleh karena itu guru harus pandai dalam memilih dan mempergunakan strategi dan metode dalam pengajaran yang akan digunakan. Sedangkan menurut Nana Sudjana, "metode pembelajaran adalah suatu cara yang dipakai oleh pengajar dalam melaksanakan proses belajar mengajar ketika melakukan interaksi dengan peserta didik didalam kelas" (Nana Sudjana, 1989:37). Faktor utama yang menentukan suatu strategi adalah tujuan utama dalam pembelajaran yang akan dicapai. Untuk memotivasi seorang murid maka guru tidak hanya memiliki atau memakai satu macam strategi saja, akan tetapi memakai beberapa rangkaian strategi yang saling mendorong terhadap efektifnya pembelajaran. Akan tetapi strategi memiliki kelemahan dan kelebihannya tersendiri, bukan hanya pada materi pembelajaran tertentu tetapi juga pada situasi tertentu. Oleh karena itu faktor situasi juga menentukan efektif tidaknya suatu strategi. Adapun tentang manajemen kelas, juga mempengaruhi proses dalam belajar. Oleh karena itu rumasan pembahasan yang diutamakan dalam penelitian ini adalah:1) Apa strategi Guru yang dilakukan dalam usaha peningkatan motivasi 
belajar pada mata pelajaran Pendidikan Agama Islam kelas VIII di SMP NU Sunan Giri Kepanjen?, 2) Bagaimana peningkatan motivasi belajar Pendidikan Agama Islam terhadap siswa kelas VIII di SMP NU Sunan Giri Kepanjen?

\section{B. Landasan Teori}

\section{Pengertian strategi Pembelajaran}

Istilah strategi berasal dari kata yunani "strategeia" (stratos artinya militer, dan "ag" artinya memimpin) yang berarti seni atau ilmu untuk menjadi seorang jendral. (Poerwodarminta, W.J.S, 1987:22). Pengertian pembelajaran sendiri adalah berasal dari kata "ajar" yang artinya petunjuk yang diberikan kepada orang supaya diketahui. Dari sebuah kata "ajar" ini lahirlah kata kerja "belajar" yang berarti berlatih atau berusaha memperoleh kepandaian atau ilmu dan kata "pembelajaran" berasal dari kata "belajar" yang mendapat awalan pem dan akhiran an yang merupakan konflik nominal yang mempunyai arti proses. (Depdikbud, 1990:664)

\section{Pengertian Guru}

Guru seyogyanya adalah seseorang yang dapat dijadikan tolak ukur keberhasilan dalam suatu bidang pendidikan dan sebagai salah satu aspek keberhasilan dalam dibidang pembangunan. Oleh sebab itu, guru sebagai salah satu aspek penting dalam bidang pendidikan seharusnya dapat mempunyai kompetensi yang kompetensi tersebut dapat menjadikan guru tersebut profesional sehingga dapat menghasilkan peserta didik yang dapat bersaing dimasyarakat dan sesuai dengan perkembangan zaman. Definisi tentang guru yang ada dilingkungan kita sehari-hari lebih kita kenal bahwa guru adalah seseorang yang mengajar dilembaga formal seperti sekolah, dan seseorang tersebut selain mempunyai kemampuan akademik juga memiliki kharisma sehingga perlu untuk diteladani dari sifat-sifatnya. Dan guru juga bisa dikatakan sebagai seseorang yang cakap dalam memanajemen suatu lingkungan tertentu yakni dalam hal ini adalah menata dan mengelola kelas. Ada juga yang berpendapat bahwa guru adalah mereka yang secara sadar mengarahkan pengalaman dan tingkah laku dari seseorang individu hingga dapat terjadi pendidikan (Hamzah, 2008:15). 


\section{Motivasi Belajar}

Menurut Maslow (Syamsu dan juntika, 2008:156) mengatakan bahwa motivasi dari diri seseorang dapat dikelompokkan kedalam esensi dari kebutuhan manusia itu sendiri yaitu suatu kebutuhan yang wajib yang kebutuhan tersebut harus dipenuhi sebelum adanya kebutuhan yang lainnya terpenuhi dan bisa dikatakan sebagai kebutuhan primer. Sedangkan motivasi belajar adalah keinginan dari dalam diri manusia itu sendiri sehingga dapat menggerakkan diri seseorang sehingga dapat menimbulkan keinginan untuk belajar. Dengan adanya motivasi siswa merasakan kebutuhan akan belajar. Motivasi bisa timbul dari faktor individu (faktor intern) dari siswa sendiri dan dari faktor luar (faktor ekstern) diri siswa itu sendiri (Dessy Artika, dkk: 2018).

\section{Peserta Didik}

Pengertian peserta didik secara Etimologi adalah seorang siswa yang sedang melakukan pembelajaran dilingkungan sekolah. Secara Termonologi peserta didik adalah anak didik atau individu yang mengalami perpindahan perilaku yang dengan adanya perpindahan tersebut memerlukan arahan dan pendidikan sebagai sarana pembentukan karakter dari seseorang atau siswa tersebut. Peserta didik adalah salah satu obyek dari implementasi sistem pendidikan nasional, yang dengan peserta didik tersebut suatu proses pendidikan dapat terlaksana dan tercapailah tujuan pemerintah untuk mewujudkan sistem pendidikan nasional. Sebagai suatu komponen pendidikan, siswa dapat dilakukan beberapa stimulus yang bertujuan untuk mengetahui ciri khas dari siswa tersebut atau peserta didik tersebut. Adapun stimulus tersebut adalah dengan dilakukannya pendekatan sosial, kejiwaan atau pedagogik.

\section{Pendidikan Agama Islam}

Pendidikan sendiri merupakan lembaga yang dengan sengaja diselenggarakan untuk mewariskan dan mengembangkan pengetahuan, keterampilan dan keahlian oleh generasi yang lebih tua kepada generasi berikutnya. Pendidikan adalah sebuah proses yang telah direncanakan oleh seseorang yang bertujuan untuk mencapai tujuan yang telah direncanakan. Sebagai salah satu usaha untuk meningkatkan mutu pendidikan adalah dengan meningkatkan juga mutu guru atau pengajar sebagai salah satu sumber daya 
manusia disekolah sehingga dapat menjadi guru yang profesional. Adapun peningkatan profesionalnya seorang guru dapat dilakukan dalam hal kepangkatan atau struktur yang guru tersebut dapat disekolah.

\section{Metode Penelitian}

\section{Sumber Data}

Suharismi Arikunto menyatakan bawasannya, sumber data adalah sumber atau obyek yang dapat menghasilkan data yang diperlukan. Jika seorang peneliti melakukan questioner atau wawancara dalam pengumpulan datanya, maka sumber data tersebut adalah responden yaitu obyek yang diwawancara yang dapat memberikan jawaban-jawaban atas masalah yang dijaukan oleh peneliti. (Suharsimi Arikunto, 2002:129). Dalam penelitian ini akan digali dari Guru Agama (guru pendidikan agama Islam) dan Guru Wali Kelas. Untuk mendapatkan data-data tersebut peneliti menggunakan sarana dan prasarana berupa alat tulis, buku catatan, alat perekam suara, kamera dan lain-lain.

\section{Prosedur Pengumpulan Data}

Langkah selanjutnya adalah teknik pengumpulan data yang dalam teknik ini merupakan esensi dari sebuah penelitian karena akan ditentukan sebagai sarana bagaimana caranya dalam mendapatkan data yang dibutuhkan. Jika seorang peneliti belum bisa menentukan teknik data apa yang akan digunakan dalam sebuah penelitiannya, maka peneliti tersebut tidak akan dapat melakukan penelitiannya secara maksimal dan tentunya data yang diperoleh jg tidak akan menjawab permasalahan-permasalan yang ada dalam penelitiannya. Untuk mendapatkan jawaban dan informasi yang dikehendaki sesuai dengan permasalahan yang dibahas, maka peneliti menggunakan beberapa teknik pengumpulan data sebagai berikut :

1. Observasi (pengamatan)

Adapun yang dimaksud dengan observasi adalah cara seorang peneliti untuk mendapatkan data yang dibutuhkan dengan pengamatan secara langsung tanpa menggunakan alat bantu tersebut, namun dalam metode ilmiah tersebut bukanlah pengamatan yang dilakukan seperti di atas. Sebuah pengamatan bisa digolongkan teknik pengumpulan data jika 
pengamatan tersebut memiliki kreteria berikut : pengamatan digunakan untuk penelitian dan telah direncanakan secara sistematik, pengamatan seharusnya mempunyai hubungan yang jelas dengan tujuan peneliti yang sudah direncanakan, pengamatan tersebut harus dinotulenkan dan diredaksikan dengan berurutan dan dapat dihubungkan dengan permasalahan yang ada dalam penelitian tersebut dan bukan sebagai hiasan saja, pengamatan dapat dicetak dan harus tetap memperhatikan kebenaran dari pengamatan dan konsistensi dari data yang diperoleh (M. Nadzir, 2017:154)

2. Interview (wawancara)

Selain dari pengumpulan data dengan cara pengamatan, maka dalam ilmu sosial data dapat juga diperoleh dengan mengadakan interview atau wawancara. Dalam hal ini informasi dan keterangan diperoleh langsung dari responden atau informansi dengan cara tatap muka dan bercakapcakap (M.Nadzir, 2017:170). Adapun tanya jawab yang telah dilakukan oleh peneliti lebih bersifat kepada wawancara tak berstruktur yang dimaksut dalam wawancara ini adalah lebih bersifat informal, yang diajukan dengan bebas saat wawancara. Wawancara ini bersifat luwes dan biasanya direncanakan agar sesuai dengan subjek dan suasana pada saat wawancara dilaksanakan (Nurul Zuriyyah, 2006:180).

3. Dokumentasi

Dokumentasi disini bisa berupa dokumen atau arsip sekolah berkenaan dengan gambaran umum sekolah SMP NU Sunan Giri, yang meliputi profil sekolah, visi-misi, letak geografis, sejarah berdirinya sekolah, struktur organisasi, kegiatan sekolah, dan lain lain. Hal ini diperlukan untuk mempermudah penelitian dalam mengambil data yang sudah ada dalam bentuk dokumen yang dimiliki sekolah, sehingga peneliti bisa menghemat waktu dan tenaga dalam mengambil data penelitian.

4. Alat Analisis

Adapun alat analisis yang digunakan dalam penelitian ini adalah interaktif model, dengan melakukan reduksi data, penyajian data dan penarikan kesimpulan/verifikasi data. 
D. Hasil

Pada bagian analisis data ini, peneliti menguraikan dari hasil wawancara yang dilakuakan kepada guru agama dan beberapa pihak-pihak yang terkait. Selain itu peneliti juga menguraikan penyajian data yang dari bahan-bahan lain seperti data-data dokumentasi yang diperlukan selama proses penelitian. Adapun analisis yang dilakukan adalah analisis interaktir dengan melakukan pengumpulan data, kondensasi data, kesimpulan dan verifikasi data.

1. Strategi Guru yang diterapkan dalam meningkatkan motivasi belajar siswa pada mata pelajaran Pendidikan Agama Islam.

Dalam tahapan mengenai bagaimana guru pendidikan agama islam dan guru wali kelas memberikan peningkatan terhadap peserta didik, dalam meningkatkan strategi motivasi. Ada banyak sekali bagaimana cara memberikan strategi dalam meningkatkan motivasi belajar siswa. Upaya guru agama memberikan strategi motivasi di SMP NU Sunan Giriyang telah dilakukan oleh Bapak Shohib adalah dengan memberikan strategi motivasi yang tidak membuat peserta didik merasa bosan dengan kegiatan belajar mengajar yaitu dengan cara:

a. Memperlihatkan video yang terkait dengan materi yang telah guru berikan.

b. Selanjutnya guru menyuruh peserta didik untuk mencoba menghubungkan materi tersebut dengan kehidupan sehari-hari.

c. Dalam memberikan pengetahuan guru menyuruh untuk membandingkan pelajaran dengan kehidupan sehari-harinya.

Sehingga motivasi dalam kegiatan belajar mengajar tidak akan membosankan, pembelajaran tidak monoton dan mudah difahami, juga motivasi tersebut memberikan pendidikan yang secara langsung diterapkan oleh pendidik. Sehingga apa strategi motivasi yang bapak Shohib berikan adalah cara guru agama tersendiri dalam memberikan strategi motivasi terhadap penyampaian materi untuk peserta didiknya. Sebagai guru wali kelasnya $\mathrm{Bu}$ Widya juga berpendapat mengenai strategi motivasi yang diberikan oleh Bapak Shohib yaitu strategi motivasi yang dilakukan sudah 
sangat membantu untuk memberikan motivasi terhadap siswa-siswinya agar mencapai target yang diinginkan dalam belajar.

Dalam meningkatkan strategi motivasi, tidak hanya berfokus kepada bagaimana guru memberikan strategi metode berupa media saja, melainkan juga memberikan beberapa motivasi yang dapat mendorong peserta didiknya agar semangat dalam belajarnya. Dengan guru memberikan motivasi dengan bentuk lain. Dan apa sajakah bentuk-bentuk lain, motivasi yang diberikan oleh guru agamanya dan guru wali kelas:

a. Guru PAI memberikan pengetahuan atau dorongan terkait seberapa penting ilmu pendidikan agama islam.

b. Guru PAI juga memberikan pujian terhadap siswa yang sudah bersemangat dalam mengikuti kegiatan belajar.

c. Guru PAI juga tidak lupa memberikan nilai kepada peserta didik yang sudah menyelesaikan setiap tugas yang diberikan oleh gurunya.

Guru wali kelas dalam memberikan motivasi terhadap anak didik yang dilakukan adalah memantau peserta didik dalam kegiatan yang diberikan oleh gurunya terutama guru agama. Tidak hanya memantau saja, melainkan guru wali kelas juga memberikan tindakan berupa mengoprak-oprak (menyuruh mengikuti kegiatan) untuk mengikuti segala kegiatan yang telah dibuat oleh guru agama, kegiatan yang diberikan oleh guru agama meliputi :

a. Kegiatan yang setiap paginya di SMP NU Sunan Giri Kepanjen melakukan mengaji al-Qur'an di setiap paginya mulai dari jam 06.30 sampai jam 07.00 sebelum kegiatan belajar mengajar dimulai (sebelum bel masuk sekolah).

b. Kegiatan Sholat dzuhur berjama'ah, sholat dzuhur yang ditempatkan di musholla sekolah SMP NU Sunan Giri Kepanjen.

c. Dan kegiatan praktek dalam sholat, beserta kegiatan praktek lainnya yang berkaitan dengan pendidikan agamanya.

2. Peningkatan motivasi belajar siswa pada mata pelajaran Pendidikan Agama Islam kelas VIII di SMP NU Sunan Giri Kepanjen.

Mengenai motivasi belajar itu sendiri adalah dorongan mental yang menggerakkan dan mengarahkan prilaku manusia, termasuk khususnya siswa- 
siswi dalam prilaku belajarnya. Sedangkan motivasi belajar dibagi menjadi dua, yaitu motivasi Instrinsik motivasi ini yang muncul dari dalam diri seseorang tanpa memerlukan rangsangan dari luar dan sedangkan motivasi Ekstrinsik ini yang berasal dari dorongan orang lain atau pengaruh dari orang lain. Dari pengamatan guru wali kelas yang sudah sehari-harinya memantau bagaimana keadaan dan peningkatan siswa-siswinya dari segi prilaku, pengetahuan terhadap belajarnya, ataupun dari segi akhlaqnya, sudah sedikit demi sedikit memiliki perubahan yang positif.

\section{E. Pembahasan}

1. Strategi Guru yang diterapkan dalam meningkatkan motivasi belajar siswa pada mata pelajaran Pendidikan Agama Islam.

Guru Agama memiliki kedudukan yang sangat penting karena menjadi sumber tenaga yang membimbing anak didiknya menuju peningkatan dalam segi keagamaannya, dengan demikian pengetahuan yang mereka peroleh dikehidupan yang akan datang tidak disalah gunakan. Seorang guru memiliki tugas dan tanggung jawab yang cukup berat apalagi sebagai guru pendidikan agamanya untuk mencerdaskan anak didiknya, maka sebagai guru harus melengkapi dirinya dengan berbagai ketrampilan yang diharapkan dapat membantu dalam menjalankan tugasnya dalam interaksi edukatif.

Dalam upaya memberikan motivasi, guru dapat menganalisis motif-motif yang melatar belakangi anak didik yang malas belajar dan prestasi yang menurun disekolah. Motivasi dapat efektif bila dilakukan dengan memperhatikan kebutuhan anak didik, penganekaragaman dalam cara belajar memberikan sebuah penguatan dan sebagainya, juga dapat memberikan motivasi pada anak didik untuk lebih bergairah dalam mencari ilmu. Didalam kegiatan belajar mengajar peranan motivasi baik intrinsik maupun ekstrinsik sangat diperlukan dengan motivasi belajar dapat mengembangkan aktivitas dan inisiatif, dapat mengarahkan dan memelihara ketekunan dalam melakukan kegiatan belajar. Menurut Bapak Shohibul Jaib, S.Pd.I selaku guru Agama di SMP NU Sunan Giri kepanjen dan guru wali kelasnya yaitu 
Bu Widya Angra menyatakan bahwa dengan adanya strategi itu siswa menjadi termotivasi, dengan memberikan strategi motivasi berupa:

a. Metode media dengan menggunakan video visual sesuai dengan pelajaran yang disuguhkan dan menghubungkan materi tersebut dengan kehidupan sehari-hari, Seperti itulah motivasi yang diberikan oleh Bapak shohib dalam meningkatkan motivasi belarnya.

b. Dengan memberikan pujian, kepada siswa yang semangat dalam belajarnya dan siswa yang sukses berhasil menyelesaikan tugas dengan baik, sehingga perlu segera diberikan pujian.

c. Memberikan nilai dalam segala tugas yang telah diberikan oleh gurunya agar siswa dapat mengetahui seberapa berhasilkan mereka dalam belar.

d. Memberikan pengertian dengan cara memberi tahu seberapa pentingkah pengetahuan terhadap Pendidikan Agama Islam.

e. Memberikan dorongan dalam segala kegiatan dengan dukungan dari wali kelas agar peserta didik selalu ikut kegiatan yang diterapkan di sekolah.

Dari beberapa strategi motivasi diatas, strategi motivasi yang dipakai oleh Bapak Shohibul Jaib, S.Pd.I selaku guru Pendidikan Agama Islam, beliau memakai strategi dan motivasi yang artinya strategi yang digunakan adalah dengan menggunakan metode media dan metode penugasan atau metode pemberian tugas sesuai dengan yang telah dituliskan dalam bab dua kajian pustaka, bahwa strategi yang digunakan menggunakan metode yang bermacam-macam sesuai kebutuhan, tujuan dan kondisi. Sedangkan yang digunakan oleh bapak shohib adalah dengan menggunakan strategi metode Individual dan Kelompok yang menurut metode belajarnya dari Winarno Surachmad. Meskipun banyak yang kurang dalam pengajaran dan kurang memantau dalam membimbing siswa-siswinya, selaku guru yang memberikan motivasi maka guru harus berusaha yang terbaik dalam pembelajaran karena guru harus memiliki strategi dalam memotivasi belajar siswa yang diakibatkan dari luar diri siswa yaitu ekstrinsik. Sehingga dapat diketahui bahwa motivasi itu terdapat dua bentuk yaitu Motivasi instrinsik dan motivasi ekstrinsikyang menjelaskan motivasi bisa tumbuh dari diri sendiri (instrinsik) atau motivasi itu tergerak dari dorongan orang lain 
(ekstrinsik). Namun motivasi yang terlihat diatas adalah motivasi yang ditumbuhkan dari dorongan orang lain (ekstrinsik).

\section{Peningkatan motivasi belajar siswa pada mata pelajaran Pendidikan Agama Islam kelas VIII di SMP NU Sunan Giri Kepanjen.}

Strategi motivasi belajar yang diberikan oleh Guru Pendidikan Agama Islam sangatlah berpengaruh dalam prestasi, ahklaq, meningkatkan pengetahuan ilmu agama dan lain sebagainya. Diantara pengaruh yang telah diperoleh oleh peserta didik di SMP NU Sunan Giri Kepanjen yang dibuktikan dengan wawancara dengan Bapak Shohib dan Ibu Widya kurang lebihnya adalah : a) Meningkatnya prilaku peserta didik terhadap guru dan kedua orang tuanya. b) Prestasi belajar yang sudah lebih baik dari sebelumnya. c) Dalam segi membaca kitab suci yaitu al-Qur'an. d) Akhlaq yang sudah sedikit demi sedikit telah diperbaiki. e) Perubahan terhadap nilai rapot buruk yang menjadi lebih baik. f) Meningkatnya pengetahuan agamanya.

Dari sini, peneliti dapat melihat dengan adanya strategi yang digunakan oleh guru motivasi belajar siswa pada mata pelajaran Pendidikan Agama Islam sudah terdapat peningkatan sedikit demi sedikit. Buktinya menurut guru wali kelasnya menyatakan bahwa sudah ada peningkatan karena dulu peserta didik sangat tidak karuan dalam arti dulu masih kurang termotivasi dalam belajarnya, meskipun masih ada anak yang harus dipantau dengan secara khusus karena setiap siswa memiliki karakter yang berbeda-beda.

Meskipun demikian, semua tidak luput dari kendala-kendala yang ada seperti kurangnya dukungan yang baik dari lingkungan diluar sekolah, terbatasnya waktu pembelajaran PAI, pengaruh negatif dari perkembangan kemajuan teknologi dan iformasi, latar belakang keluarga dan juga seperti untuk peserta didik yang sangat sulit untuk dibimbing dalam kebaikan, sehingga untuk peserta didik yang seperti itu dalam memberikan motivasi hanya akan bertahan dalam dua hari. Sehingga guru sangatlah penting dalam memberikan dorongan motivasi terhadap peserta didik, dengan demikian siswa-siswi tak lepas dari cara untuk belajar lebih baik. Lingkungan di luar 
sekolahpun juga menjadi peran yang sangat penting terhadap peserta didik, dikarenakan pengaruh yang buruk akan rentan terpengaruh terhadap peserta didik dan pengaruh lingkungan yang baik pula akan mendorong peserta didik menjadi pribadi yang baik, sehingga dukungan motivasi dari gurulah yang penting terhadap siswa-siswinya dalam pembelajaran disekolah untuk menjadi benteng ketika bersama teman dan masyarakat.

\section{F. Kesimpulan}

Adanya penelitian ini adalah sebagai jawaban dari beberapa strategi yang harus dilakukan oleh seorang guru untuk melaksanakan proses pembelajaran. Seorang guru harus mempunyai strategi yang ideal untuk dapat mengajar didalam kelas sesuai dengan kondisi yang biasanya berbeda pada tiap-tiap jenjangnya. Strategi guru juga diperlukan untuk meningkatkan motivasi belajar siswa-siswi yang ada dilembaga pendidikan yang diajarnya. Adanya penerapan strategi tersebut diharapkan para siswa dapat meningkatkan prestasi belajarnya. Dengan prestasi belajarnya meningkat, peserta didik akan mempunyai akhlak yang baik pula seiring dengan itu perilaku yang tercermin akan semakin baik pula. Adapun yang terjadi adalah bahwa adanya penerapan strategi tersebut adalah untuk meningkatkan mutu pendidikan yang harus dilakukan oleh seorang pengajar.

\section{Daftar Pustaka}

Arikunto Suharsimi. 2002. Prosedur Penelitian Suatu Pendekatan Praktek, Jakarta. Renika Cipta

Artika, Dessy dkk, 2017. Jurnal ilmiyah pendidikan guru sekolah dasar.

Dep. Pend. Dan Kebudayaan. 1990. Kamus Besar Bahasa Indonesia. Jakarta. Balai Pustaka

Hamzah, Buno. 2007. Model Pembelajaran. Jakarta. PT. Bumi Aksara.

Nazir, Moh. 2017. Metode Penelitian, Galia Indonesia. Cet 11, Bogor: Jl. Ranca Maya

Ramayulis H, Samsul Nizar. 2010 Filsafat Pendidikan Islam. Jakarta. Kalam Mulia

Sudiyono. 2009. Ilmu Pendidikan Islam, Jakarta. PT. Rineka Cipta

Sugiono. 2015. Metode Penelitian Pendidikan. Cet 22, Bandung. Alfabeta

Zuriyah Nurul. 2006. Metodologi Penelitian Sosial dan Pendidikan. Jakarta. Bumi Aksara 